\title{
PENGARUH REGULASI DIRI TERHADAP PROKRASTINASI AKADEMIK PADA SISWA SMA
}

\author{
Putri Ramadhani Ayu Ardina \& Dwi Kencana Wulan \\ e-mail: kencana.wulan@gmail.com \\ Psikologi, Universitas Negeri Jakarta
}

Kampus D UNJ J1. Halimun Raya No.2 Jakarta Selatan

\begin{abstract}
Abstrak: Prokrastinasi akademik merupakan salah satu permasalahan yang dihadapi siswa dalam dunia pendidikan, biasanya disebabkan oleh rasa bosan atau kelelahan. Sementara, di sisi lain siswa harus memiliki kemampuan meregulasi diri dalam mencapai tujuan akademis. Penelitian ini bertujuan untuk mengetahui pengaruh regulasi diri terhadap prokrastinasi akademik dengan menggunakan metode kuantitatif dengan skala psikologi berupa kuesioner. Instrumen yang digunakan pada penelitian ini disusun berdasarkan teori prokrastinasi akademik Ferrari dan teori regulasi diri pada remaja dari Barkley. Penelitian dilakukan pada bulan Juni 2016. Sampel penelitian ini adalah siswa kelas X SMA Negeri 10 Jakarta. Teknik pengambilan sampel yang digunakan adalah cluster random sampling. Analisis statistik yang digunakan untuk menguji hipotesis adalah analisis regresi dengan menggunakan program SPSS versi 19 dan Rasch Model. Hasil penelitian menunjukan terdapat pengaruh yang signifikan antara regulasi diri terhadap prokrastinasi akademik. Pengaruh yang dihasilkan bersifat negatif. Hal ini menunjukan semakin tinggi regulasi diri, maka akan berdampak terhadap menurunnya prokrastinasi akademik. Besar pengaruh yang dihasilkan regulasi diri terhadap prokrastinasi akademik adalah $29,3 \%$ dan sisanya 70,7\% dipengaruhi oleh faktor lain.
\end{abstract}

Kata-kata kunci: pendidikan, prokrastinasi, prokrastinasi akademik, regulasi diri, murid sekolah menengah atas

\section{EFFECTS OF SELF-REGULATION TOWARDS ACADEMIC PROCRASTINATION FOR SENIOR HIGH SCHOOL STUDENT}

\begin{abstract}
Academic procrastination is one of the problems student usually faced, caused by fatigue or boredom. While in the other side, students needs the ability to regulate themselves for striving their goals. This study aims to determine the influence of self-regulation towards academic procrastination using quantitative method with psychological scale in questionnaire form. This research instrument was developed based on the theory of academic procrastination by Ferrari and self-regulation theory by Barkley. This research was conducted in June 2016. The samples of this study were the tenth grade students of SMA Negeri 10 Jakarta (State Senior High School of Jakarta). The sampling technic used was cluster random sampling. The analytical statistic used to test the hypothesis was regression analysis using SPSS program verse 19 and Rasch Model. The Result of this study indicates that there is negative effect of self-regulation towards academic procrastination. It shows that the higher self-regulation performed, then the lower academic procrastination will become. The influence which resulted by self-regulation towards academic procrastination is $29,3 \%$ and the rest $70,7 \%$, is caused by another factor.
\end{abstract}

Keywords : education, procrastination, academic procrastination, self-regulation, high school student.

\section{PENDAHULUAN}

Pendidikan merupakan alat terpenting dalam pembibitan sumber daya manusia yang berkualitas. Hal ini sesuai dengan pengertian pendidikan menurut UU No. 20 Tahun 2003 Pasal 1 Ayat 1 Republik Indonesia, yaitu: "Pendidikan adalah usaha sadar dan terencana untuk mewujudkan suasana belajar dan proses pembelajaran agar peserta didik secara aktif mengembangkan potensi dirinya untuk memiliki kekuatan spiritual keagamaaan, pengendalian diri, kepribadian, kecerdasan, akhlak mulia, serta ketrampilan yang diperlukan dirinya, masyarakat, bangsa, dan negara." 
Undang-undang sistem pendidikan nasional tersebut menjadi landasan hukum bagi pemerintah dalam rangka peningkatan kualitas pembelajaran (Instructional Quality) karena muara dari berbagai program pendidikan adalah pada terlaksananya program pembelajaran yang berkualitas.

Pendidikan Indonesia saat ini masih berada dalam tahap perbaikan menuju arah yang lebih baik. Pergantian kurikulum merupakan salah satu usaha pemerintah Indonesia dalam perbaikan sistem pendidikan dan mencapai tujuan pendidikan seperti yang tertera dalam UU No. 20 Tahun 2003. Tercatat sampai tahun 2016, dunia pendidikan di Indonesia telah berganti kurikulum sebanyak 10 kali. Dimulai dari kurikulum pendidikan tahun 1947, 1952, 1964, 1968, 1975, 1984 (CBSA), 1994, 2004 (KBK), 2006 (KTSP) sampai yang terakhir dan digunakan sampai saat ini yaitu kurikulum 2013 (Brillio.net, 2 Mei 2015).

Faktanya, penerapan kurikulum 2013 saat ini membuat banyak siswa merasa terbebani dan lelah. Hal ini berdasarkan pada penelitian awal dan wawancara pada tanggal 1 maret 2016 terhadap beberapa orang siswa sekolah menengah atas di DKI Jakarta. Narasumber mengatakan bahwa terdapat banyak beban mata pelajaran yang harus diikuti perminggunya. Selain itu, sebagai siswa, narasumber diminta untuk proaktif dalam kegiatan pembelajaran, dan mendapatkan tugas yang diberikan hampir setiap hari dikarenakan adanya kewajiban nilai tugas per kompetensi dasar per mata pelajaran, maka setiap guru pun terpaksa memberikan tugas.

Akibat banyaknya tugas dan tuntutan yang diberi, hal-hal tersebut membuat siswa merasa bosan dan lelah. Kemudian, rasa bosan dan lelah mengakibatkan siswa menjauhi tugastugas yang harus diselesaikan, dan cenderung untuk menunda serta mengulur-ulur waktu dalam memulai, mengerjakan, hingga menuntaskan. Seperti pernyataan narasumber berikut "Saya menjadi malas untuk belajar dan menunda belajar dan mengerjakan tugas yang setumpuk karena sudah lelah dengan sekolah ditambah dengan tugas - tugas yang setiap mata pelajaran pasti ada saja 1 atau 2 tugas."

Narasumber mengaku sadar ketika menunda-nunda pengerjaan tugas yang ada, waktu-waktu yang narasumber sadari harus diisi untuk mengerjakan LK (Lembar Kerja) atau tugas, diisi dengan kegiatan lain yang bersifat lebih menyenangkan dan menghilangkan kebosanan. Selain itu, narasumber juga mengatakan bahwa tidak dapat mengendalikan diri atau menghentikannya. Pada beberapa narasumber, situasi di atas (beban yang berat) mampu menimbulkan stres. Penundaan atau penghindaran dilakukan individu sebagai suatu bentuk coping yang digunakan untuk menyesuaikan diri terhadap situasi yang mendatangkan stres (Kendall \& Hamen, 1998, h. 305; sanderson, 2004 h.128).

Untuk hasil penelitian awal yang lebih mendalam, peneliti mengunjungi salah satu SMA Negeri di kawasan Jakarta Pusat, yaitu SMA Negeri 10 Jakarta. Berdasarkan hasil penelitian awal tersebut, terkait program belajar dan mengajar, pada sekolah, setiap minggunya guru setiap mata pelajaran memberikan LK (Lembar Kerja) yang harus dikumpulkan sesuai dengan tenggat waktu yang ditentukan sesuai dengan acuan Kurikulum 2013. Namun hasil dari penelusuran peneliti dan wawancara, hampir $65 \%$ siswa kelas X (Data dari guru BK SMA Negeri 10 Jakarta) cenderung melakukan prokrastinasi, misalnya siswa tidak mengumpulkan LK tepat dengan waktu yang ditentukan $65 \%$ siswa tersebut harus "dikejar" terlebih dahulu oleh guru mata pelajaran terkait, baru setelah itu mengumpulkan LK ataupun tugas. Hal tersebut, menurut hasil wawancara pada beberapa guru mata pelajaran menjadi masalah dan mengganggu keberlangsungan program belajar maupun mengajar.

Berdasarkan hasil wawancara pada beberapa siswa kelas XSMA Negeri 10 Jakarta, ditemukan siswa mengaku kaget dengan penerapan pembelajaran di SMA karena berbeda dengan pembelajaran sebelumnya ketika di SMP. Siswa kaget karena sudah dihadapkan dengan peminatan begitu masuk sekolah menjadi X IIS untuk Ilmu Sosial dan X MIA untuk ilmu Alam. Selain itu, banyaknya beban belajar, tugas yang menumpuk, diskusi kelompok, kewajiban untuk aktif dan presentasi membuat siswa bosan, dan lelah sehingga cenderung menghindari dan menunda kewajiban akademik yang ada.

Perilaku menunda waktu dalam literatur ilmiah disebut sebagai prokrastinasi (procrastination). Istilah prokrastinasi berasal dari bahasa Latin procrastination dengan awalan pro yang berarti mendorong maju atau bergerak maju dan akhiran crastinus- yang berarti keputusan hari esok, atau jika digabungkan menjadi menangguhkan atau menunda sampai hari berikutnya (Steel, 2007). American College Dictionary menjelaskan tentang prokrastinasi sebagai menangguhkan suatu tindakan untuk melaksanakan suatu tugas yang akan dilaksanakan pada waktu atau hari lainnya (Burka dan Yuen, 1983).

Prokrastinasi dapat dikatakan sebagai suatu penundaan atau kecenderungan menunda-nunda 
memulai suatu kerja, namun prokrastinasi juga bisa dikatakan sebagai penghindaran tugas, yang diakibatkan perasaan tidak senang terhadap tugas dan ketakutan untuk gagal dalam mengerjakan tugas (Ghufron, 2003). Suatu penundaaan dikatakan sebagai prokrastinasi, apabila penundaan itu dilakukan pada tugas yang penting, dilakukan berulang-ulang secara sengaja dan menimbulkan perasaan tidak nyaman, secara subjektif dirasakan oleh seorang prokrastinator (Solomon dan Rothblum, 1984). Pendapat ini sejalan dengan ulasan Ellis dan Knaus yang mendefinisikan prokrastinasi sebagai suatu kegagalan untuk memulai maupun menyelesaikan suatu pekerjaan atau aktivitas pada waktu yang telah ditentukan (Rachmahana, 2002).

Penelitian yang telah dilakukan oleh Aitken menyatakan bahwa prokrastinasi yang terjadi dalam masyarakat pada umumnya berkisar antara 25\% sampai 70\% (Rachmahana, 2002). Selanjutnya, penelitian yang dilakukan oleh Green (1992) menjelaskan bahwa dampak dari prokrastinasi adalah adanya penurunan kualitas kehidupan seseorang yang berakibat pada rendahnya kepuasan hidup prokrastinator tersebut. Seorang prokrastinator akan mengalami ketidaknyamanan psikologis yang dapat menyusahkan individu tersebut misalnya rasa bersalah dan penyesalan yang mendalam akibat tidak dapat menjalankan tugasnya dengan baik dan tepat waktu.

Prokrastinasi terjadi pada berbagai aspek kehidupan manusia. Pada lingkup akademik, penundaan yang dilakukan dinamakan dengan Prokrastinasi Akademik. Menurut Ferrari \& McCown (1995), faktor-faktor penyebab terjadinya prokrastinasi akademik ada dua macam, yaitu faktor dari dalam individu (internal) dan luar individu (eksternal). Ferrari \& McCown (1995) menyatakan aspek-aspek prokrastinasi meliputi (a) penundaan ketika memulai maupun menyelesaikan kinerja dalam menghadapi tugas; (b) kelambanan dalam mengerjakan tugas; (c) kesenjangan waktu antara rencana dengan kinerja aktual dalam mengerjakan tugas; serta (d) kecenderungan untuk melakukan aktivitas lain yang dipandang lebih mendatangkan hiburan dan kesenangan.

Hasil penelitian awal juga menunjukan bahwa narasumber dituntut untuk mampu meregulasi diri di setiap pembelajaran dengan menjadi pro-aktif. Juga dalam memenuhi tujuan-tujuan jangka pendek narasumber dalam setting akademik seperti tugas yang sedang dikerjakan dan harus segera dikerjakan. Sampai tujuan jangka panjang seperti ujian-ujian sekolah, hingga menuju ke tingkat pendidikan selanjutnya (Perguruan Tinggi). Prokrastinasi adalah jenis dari anti motivasi yang berhubungan dengan rendahnya regulasi diri, efikasi diri, dan self-esteem dan berasosiasi dengan tingginya kecemasaan serta stres (Klassen, dkk., 2009).

Bandura (1991) meyakini bahwa manusia menggunakan strategi reaktif dan proaktif untuk mengatur atau meregulasi dirinya. Zimmerman (2000) mendefinisikan regulasi diri sebagai proses menghasilkan pikiran, perasaan dan tindakan, merencanakan dan mengadaptasikannya secara terus menerus untuk mencapai tujuan-tujuan. Regulasi diri adalah kemampuan untuk merencanakan, mengarahkan, dan memonitor perilaku untuk mencapai suatu tujuan tertentu dengan melibatkan unsur fisik, kognitif, emosional, dan sosial (Brown, dalam Neal \& Carey 2005). Zimmerman (Ormrod, 2003), menjelaskan bahwa seseorang disebut memiliki regulasi diri jika pikiran dan perilakunya berada di bawah kendalinya sendiri, tidak dikendalikan oleh orang lain dan lingkungan. Zimmerman (1989) juga mengatakan bahwa siswa yang memiliki regulasi diri dalam belajar merupakan siswa yang aktif secara metakognitif, motivasi dan perilakunya dalam proses belajar.

Uraian-uraian di atas memunculkan pertanyaan seperti apakah terdapat pengaruh regulasi diri terhadap prokrastinasi akademik yang dilakukan para siswa?. Karena terdapat dinamika dari kedua variabel yang ada. Berdasarkan rumusan masalah di atas, penulis tertarik untuk mengkaji lebih dalam mengenai regulasi diri dan prokrastinasi akademik pada siswa kelas X SMA Negeri 10 Jakarta serta pengaruh Regulasi Diri terhadap Prokrastinasi Akademik dengan melakukan penelitian berjudul: Pengaruh Regulasi Diri Terhadap Prokrastinasi Akademik Pada Siswa Siswi Kelas X SMA Negeri 10 Jakarta.

Prokrastinasi akademik adalah jenis penundaan yang dilakukan pada jenis tugas formal yang berhubungan dengan tugas akademik atau kinerja akademik (Ferrari, 1995). McCloskey (2011) mendefinisikan prokrastinasi akademik sebagai sebuah kecenderungan untuk menunda kegiatan dan perilaku yang terkait dengan pendidikan. Milgram, Batori \& Mowrer mendefinisikan prokrastinasi akademik merupakan sebuah tendensi untuk menunda atau menghindari pekerjaan atau tugas sekolah dan belajar (Pychyl, 2000).

Sementara itu, Solomon \& Rothblum mendefinisikan prokrastinasi akademik dengan lebih 
spesifik, yakni sebagai menunda kewajiban akademik seperti belajar untuk mempersiapkan ujian dan menunda pekerjaan rumah, terkadang atau secara konstan (Kendemir, 2014).

Dari definisi di atas dapat disimpulkan bahwa prokrastinasi akademik merupakan kecenderungan menunda yang lebih difokuskan pada aspek pengerjaan tugas-tugas akademik atau setting pendidikan. Secara lebih khusus, individu yang menjadi fokus dalam penelitian ini adalah siswa.

Ferrari dkk., (1995: 16) mengatakan bahwa sebagai suatu kecenderungan menunda, prokrastinasi akademik dapat termanifestasikan dalam indikator tertentu yang dapat diukur dan diamati ciri-cirinya, yaitu (a) perilaku menunda pada saat memulai hingga ketika menyelesaikan tugas, (b) keterlambatan dalam mengerjakan tugas, (c) kesenjangan waktu antara rencana pengerjaan dan kinerja yang ada, dan (d) memilih melakukan tindakan lain yang lebih menyenangkan daripada mengerjakan tugas yang harus dikerjakan dan diselesaikan.

Solomon dan Rothblum (1984) menyebutkan enam area akademik yang sering dilakukan dalam ranah prokrastinasi akademik, yaitu (1) menulis: melakukan penundaan terhadap tugas yang berhubungan dengan kewajiban menulis karangan, laporan dan makalah; (2) belajar untuk ujian: melakukan penundaan belajar dan belajar hanya pada saat ujian tengah semester, ujian akhir semester dan pada saat kuis; (3) membaca: menunda membaca buku atau referensi yang berkaitan dengan tugas akademik mingguan; (4) kinerja administratif: penundaan pekerjaan yang berhubungan dengan kewajiban administratif seperti menyalin catatan, mendaftar sebagai peserta praktikum atau melakukan registrasi; (5) menghadiri pertemuan: keterlambatan pada saat menghadiri kelas dan rapat; dan (6) kinerja akademik secara keseluruhan: penundaan mengerjakan atau menyelesaikan tugas-tugas akademik secara keseluruhan.

Selanjutnya, regulasi diri didefinisikan sebagai suatu proses di mana seseorang menghasilkan pikiran, perasaan dan tindakan, merencanakan dan mengadaptasikannya secara terus-menerus untuk mencapai tujuan-tujuan personal (Zimmerman, 2000).

Watson (1989) menyatakan regulasi diri sebagai sistem pengendalian diri terhadap respon lingkungan yang melibatkan pengaturan perhatian, ingatan dan pikiran yang terjadi secara spontan. Hal ini mendukung teori regulasi diri dari Barkley (1997) yang mengatakan bahwa regulasi diri merupakan kemampuan untuk mengaktivasi secara fleksibel, monitor, mencegah, tekun dan atau mengadaptasi perilaku, perhatian, strategi emosi dan kognisi dalam merespons arahan-arahan dan petunjuk dari dalam, stimulus lingkungan dan timbal balik dari orang lain, dalam rangka mencapi tujuan personal yang relevan.

Dari pengertian di atas, dapat dikatakan bahwa regulasi diri adalah aktivitas individual yang melibatkan pengaturan perhatian, pikiran, perilaku dan emosi secara serentak dalam rangka usaha merancang, mengontrol dan mengarahkan perilaku diri agar sesuai dengan tujuan yang akan dicapai sehingga tidak terjadi kesenjangan antara pola pikir dan perilaku.

Moilanen (2007) menetapkan empat domain dalam regulasi diri pada remaja. Pertama, emosi, yaitu suatu perasaan yang mendorong individu untuk merespon atau bertingkah laku terhadap stimulus, baik yang berasal dari dalam maupun dari luar dirinya. Kedua, behavioral atau perilaku, yaitu respons atau tindakan yang diberikan individu terhadap kehadiran stimulus; bagaimana individu mampu memberikan response yang sesuai dengan tujuan yang dimiliki. Ketiga, attentional atau perhatian, yaitu pemusatan tenaga atau kekuatan usaha Individu terhadap tujuan, yang termanifestasi dalam kesadaran yang menyertai suatu aktivitas yang dilakukan dan perilaku yang dihasilkan. Keempat, kognitif, yaitu proses mental yang dilakukan individu dalam memperoleh pengetahuan dan memanipulasi pengetahuan melalui aktivitas mengingat, menganalisis, memahami, menilai, menalar, membayangkan, dan berbahasa.

Moilanen (2007) mengembangkan teori regulasi diri pada remaja dari teori Barkley melalui modelnya yang bernama Barkley's hybrid model (1997, 2004). Pada teori ini, regulasi diri dan dimensinya mengacu kepada "motor control system" (yang mana juga diketahui sebagai "motor control/ fluency/ syntax;"), yaitu merupakan ouput yang dapat diamati dari executive function atau fungsi eksekutif.

Fungsi eksekutif merupakan proses mental individu untuk mampu merencanakan, memfokuskan perhatian, mengingat instruksi atau dengan kata lain rangkaian kemampuan dan kegiatan untuk menyaring gangguan, memprioritaskan tugastugas, menetapkan dan mencapai tujuan, dan mengontrol impuls-impuls (Harvard Edu, 2016). Proses mental tersebut merupakan penjelasan baru terkait pemahaman regulasi diri modern. Prosesproses tersebut adalah sebagai berikut.

Pertama, monitor: kepekaan dalam merespon timbal balik. Memonitor sejauh mana kemajuan dari 
strategi-strategi yang digunakan untuk mencapai tujuan maupun sejauh mana letak tujuan itu sendiri. Kedua, persevering: konstan dalam mengarahkan tindakan menuju tujuan. Ketiga, activating: melaksanakan respons-respons yang mengarah kepada tujuan dan melaksanakan tindakan-tindakan kompleks motor sekuens (pengulangan, proses trial $\mathcal{E}$ error). Keempat, adapting: fleksibilitas tindakan sesuai dengan kondisi yang sedang terjadi dan mampu berhubungan kembali dengan tugas meski diikuti dengan gangguan. Kelima, inhibiting: mencegah respons-respons dari dalam diri maupun lingkungan luar yang tidak sesuai dengan tugas yang ada dan mengontrol perilaku berdasarkan informasiinformasi yang direpresentasikan dari dalam diri atau telah dimiliki individu.

Barkley menunjukkan bahwa pemahaman waktu merupakan elemen kunci dari regulasi diri: remaja mampu merencanakan atau mempersiapkan diri untuk kesempatan, baik dalam waktu yang pendek maupun panjang, sementara anak-anak terbatas pada peristiwa yang berjangka waktu pendek (Moilanen, 2007). Konteks waktu tersebut yaitu (a) jangka pendek dan (b) jangka panjang. Regulasi diri jangka pendek dioperasionalkan sebagai impuls, perhatian atau kontrol emosi dalam apa yang sedang terjadi. Sebaliknya, regulasi diri jangka panjang melibatkan kontrol impuls atau usahausaha terarah melalui periode waktu yang lebih lama. Durasi ini bisa berlangsung beberapa minggu, bulan atau tahun. Regulasi diri jangka panjang juga melibatkan perencanaan substansial.

Rata-rata siswa SMA berusia 15 - 19 tahun, yang mana menurut Monk (2001) sedang berada pada masa remaja madya. Pada tahap remaja madya, remaja sudah memasuki tahap berpikir operasional formal, yakni sudah mampu berpikir secara sistematis mengenai hal-hal yang abstrak serta sudah mampu menganalisis secara lebih mendalam mengenai sesuatu hal (Hurlock, 1999).

Developmental School Counseling Programs (Sciarra, 2004), menyebutkan kompetensi yang harus dikuasai oleh siswa Sekolah Menengah Atas kelas X yakni harus mempunyai kemampuan untuk mengklarifikasi peranan nilai dalam pilihan karir, membedakan pendidikan dan keahlian yang dibutuhkan dalam karir berdasarkan minat, menyadari pengaruh pada pekerjaan atau pilihan karir pada area kehidupan yang lain, mulai mengases secara realistik potensi mereka dalam lapangan yang bervariasi, mengembangkan keahlian dalam memprioritaskan kebutuhan yang dihubungkan dengan perencanaan - perencanaan masa depan seperti perguruan tinggi atau karir.

Berdasarkan penjelasan di atas, dapat disimpulkan bahwa diantara tugas siswa kelas X SMA yang sedang berada dalam tahap remaja madya adalah mempersiapan karir atau melanjutkan pendidikan tinggi guna mencapai kematangan dalam pilihan pekerjaan atau profesi.

\section{METODE PENELITIAN}

Penelitian ini menggunakan 120 orang subjek penelitian. Populasi dari penelitian ini adalah individu yang berstatus sebagai siswa kelas $X$ di SMA Negeri 10 Jakarta. Penelitian dilakukan pada bulan Juni 2016

Pendekatan yang digunakan untuk memilih sampel adalah cluster random sampling. Metode penelitian ini merupakan penelitian kuantitatif, Metode penelitian kuantitatif dapat diartikan sebagai metode penelitian yang berlandaskan pada filsafat positivisme, digunakan untuk meneliti pada populasi atau sampel tertentu, pengumpulan data menggunakan instrumen penelitian, analisis data bersifat statistik, dengan tujuan menguji hipotesis yang telah di tetapkan (Sugiyono, 2011). Berdasarkan tingkat eksplanasinya, penelitian ini merupakan penelitian asosiatif (Sugiyono, 2003). Hal tersebut dikarenakan penelitian ini mencari hubungan antar variabel yang bersifat kausal atau sebab-akibat. Salah satu variabel mempengaruhi variabel yang lain yaitu, pengaruh Regulasi Diri (independent variable) terhadap Prokrastinasi Akademik (dependent variable).

Alat ukur yang digunakan pada penelitian ini peneliti susun sendiri berdasarkan teori Prokrastinasi Akademik dari Ferrari (1995) untuk variabel Prokrastinasi Akademik dan Teori Regulasi Diri pada Remaja dari Barkley (Moilanen, 2007) untuk variabel Regulasi Diri. Sampel penelitian ini adalah siswa kelas X SMA Negeri 10 Jakarta. Penelitian ini menggunakan skala likert. Terdapat empat pilihan jawaban, yaitu (a) tidak sesuai, (b) hampir sesuai, (c) sesuai, dan (d)sangat sesuai.

Prosedur penelitian ini terdiri dari tiga tahap. Pada tahap pertama, peneliti mencari teori yang relevan terkait kedua variabel penelitian dari berbagai sumber. Selanjutnya peneliti melakukan expert judgment atas kedua instrumen kepada dosen di Universitas Negeri Jakarta dan uji keterbacaan kepada sejumlah orang yang sesuai dengan karakteristik subjek penelitian. Berdasarkan evaluasi dari hasil expert judgment dan uji keterbacaan, peneliti 
menyusun instrumen tersebut untuk di uji coba.

Penelitian dimulai dengan melakukan uji coba untuk menguji validitas dan reliabilitas instrumen yang akan digunakan. Uji coba penelitian ini dilakukan pada 35 orang responden siswa kelas $\mathrm{X}$ di SMA Negeri 10 Jakarta. Selanjutnya peneliti mengolah data untuk mengetahui validitas dan reliabilitas serta seleksi aitem instrumen tersebut. Akhirnya, berdasarkan hasil uji coba didapatkanlah kuesioner yang akan dipergunakan untuk mengumpulkan data selanjutnya.

Tahap selanjutnya adalah proses pengumpulan data. Pengumpulan data dilakukan dengan menyebar kuesioner kepada siswa kelas X di SMA Negeri 10 Jakarta sebanyak 120 orang. Setelah seluruh data didapatkan, dilakukan skoring dan input data untuk dilakukan pengolahan data lebih lanjut. Pengolahan data dilakukan dua tahap melalui aplikasi Rasch versi 3.73 untuk mendapatkan nilai reliabilitas dan dilanjutkan dengan aplikasi SPSS versi 16.0 untuk melakukan uji asumsi. Berdasarkan pengolahan data melalui aplikasi SPSS didapatkan hasil yang memenuhi syarat uji normalitas dan linearitas sebagai uji hipotesis. Oleh karena itu, langkah selanjutnya adalah melakukan uji hipotesis menggunakan uji statistika, yaitu uji Analisis Regresi.

\section{HASIL DAN PEMBAHASAN}

Sebelum melihat apakah hipotesis penelitian yang diajukan diterima, peneliti melakukan uji asumsi yang meliputi uji normalitas dan uji homogenitas untuk memastikan bahwa data memang layak digunakan dalam penelitian. Data yang digunakan pada uji normalitas dan linearitas merupakan data logis yang didapat dari hasil olah data menggunakan Rasch Model.

Untuk melihat apakah data telah sesuai dengan kurva normal, maka dilakukan uji normalitas dengan Kolmogorov-Smirnov. Data berdistribusi normal apabila nilai Kolmogorov-Smirnov Z (KSZ) variabel lebih besar dari 1,97 atau $p>1,97$. Berikut adalah hasil uji normalitas variabel regulasi diri terhadap prokrastinasi akademik pada siswa kelas X SMA Negeri 10 Jakrta.

Sebaran data pada variabel Regulasi Diri memiliki nilai signifikansi 1,11 ( $p>1,97$ ). Hal ini menunjukkan bahwa sebaran data pada variabel pengambilan keputusan rasional bersifat normal. Sedangkan sebaran data pada variabel Prokrastinasi Akademik memiliki nilai signifikansi 1,67 ( $\mathrm{p}>1,97)$.
Hal ini menunjukkan bahwa sebaran data pada variabel Prokrastinasi Akademik bersifat normal.

Langkah selanjutnya adalah pengujian linearitas. Uji linearitas terpenuhi jika nilai p lebih kecil dari nilai $\alpha(0,05)$ atau $p<0,05$. Hasil pengujian tersebut menunjukkan bahwa kedua variabel linier karena nilai $p=0,00$ dan nilai $\alpha=0,05$.

Karena hasil uji asumsi terpenuhi, maka selanjutnya dilakukan uji Persamaan Regresi. Hasil uji persamaan regresi data pada penelitian ini menghasilkan hubungan yang bersifat negatif, hal ini didapatkan melalui uji analisa regresi satu prediktor yang menghasilkan persamaan Prokrastinasi Akademik $=(1.148)+(-0,606)$ Regulasi diri. Dimana diketahui bahwa jika Regulasi Diri mengalami kenaikan sebesar satu satuan, maka Prokrastinasi Akademik akan mengalami penurunan sebesar 0,606.

Selanjutnya, dilakukan uji hipotesis. Hasil uji hipotesis menghasilkan F hitung sebesar 50,202 dengan nilai p sebesar 0,000 . Jika nilai p dibandingkan dengan nilai $\mathrm{a}=0,005$ maka $\mathrm{p}<\mathrm{a}$ yang artinya Hipotesis alternatif ( $\mathrm{Ha}$ ) dalam penelitian ini diterima dan Hipotesis nol (Ho) pada penelitian ini ditolak. Jika menggunakan perbandingan antara $F$ hitung dan F tabel $(1 ; 118)$, hasilnya F tabel sebesar 3,92 yang artinya F hitung > F tabel. Kesimpulannya adalah $\mathrm{Ha}$ diterima dan Ho ditolak, dengan kata lain terdapat pengaruh variabel regulasi diri terhadap variabel prokrastinasi akademik. Pengaruh yang dimiliki regulasi diri terhadap prokrastinasi akademik sebesar 29,3\% (Adjusted R Square; 0,293) sedangkan 70,2\% lainnya dipengaruhi oleh faktor yang tidak diteliti dalam penelitian ini.

Hal ini sesuai dengan hasil penelitian dari Ryan \& Conell bahwa prokrastinasi akademik tidak hanya merupakan bentuk kegagalan regulasi diri, namun juga disebabkan oleh adanya amotivasi dan motivasi intrinsik. Siswa yang memiliki amotivasi atau tidak terdorong untuk meregulasi diri pada perilaku akademik akan mudah untuk lebih melakukan prokrastinasi. Mereka juga menyatakan bahwa bentuk regulasi diri yang kurang pada bidang akademik berhubungan dengan kurangnya ketekunan, emosi negatif, dan ketidaksesuaian antara sikap dan perilaku. Ketiga hal tersebut merupakan faktor-faktor yang mengacu pada prokrastinasi (Senecal, 1995).

Hasil dari data deskriptif penelitian sendiri menunjukan bahwa, sebagian besar siswa kelas $X$ di SMA Negeri 10 Jakarta memiliki tingkat kategorisasi skor prokrastinasi akademik yang dimiliki tergolong tinggi yaitu sebesar $54 \%$ dan sekitar $58 \%$ siswa 
memiliki tingkat kategorisasi skor regulasi diri yang rendah. Di mana hal ini menunjukan bahwa lebih dari setengah jumlah siswa di SMA Negeri 10 Jakarta memiliki permasalahan prokrastinasi akademik dan regulasi diri. Hal ini sesuai dengan wawancara yang dilakukan oleh peneliti ke beberapa responden. Siswa mengaku bahwa salah satu kesulitan yang dihadapi dalam pembelajaran adalah rasa bosan yang mengakibatkan kecenderungan untuk menunda dan menghindar. Tentunya hal ini harus diminimalisir, mengingat siswa harus meregulasi diri guna memenuhi tujuan-tujuan jangka panjang yang akan dihadapi mendatang maupun jangka pendek yang dihadapi sekarang. Jika prokrastinasi akademik sudah sampai tahap kronis, maka individu akan kesulitan dalam memonitor, mengontrol dan mencegah tindakan-tindakan dalam meraih tujuan (Paris \& Paris, 2011) yang artinya akan menyebabkan kegagalan dalam meregulasi diri. Hal ini memperkuat pernyataan Lay \& Schouwenburg, bahwa individu yang melakukan prokrastinasi biasanya gagal untuk memenuhi rencana-rencana mereka (Sperling, 2012).

Pengaruh yang dihasilkan regulasi diri terhadap prokrastinasi akademik bersifat negatif. Hal tersebut menunjukan bahwa semakin tinggi regulasi diri maka akan semakin rendah tingkat prokrastinasi akademik. Sebaliknya, semakin tinggi tingkat prokrastinasi akademik maka akan semakin rendah tingkat regulasi diri. Maka dapat diketahui bahwa regulasi diri dapat menjadi salah satu strategi dan solusi untuk mengurangi prokrastinasi akademik. Jika seorang individu memiliki regulasi diri yang baik, maka individu tersebut akan mampu untuk mengerahkan perhatian, fikiran, emosi dan tindakan ke tujuan (Zimmerman, 2000). Penelitian yang dilakukan oleh Ottingen et Al. (2015) menyatakan bahwa regulasi diri yang efektif yang dapat digunakan dalam rangka memperbaiki manajemen waktu dan akan meningkatkan peningkatan fungsi hidup sehari-hari dan pengembangan jangka panjang, misalnya perubahan perilaku atau sikap pada domain akademik.

Gollwitzer (2010) mengatakan bahwa prokrastinasi dapat diatasi dengan memulai perencanaan dan mengimplementasikannya melalui regulasi diri. Regulasi diri yang baik akan menghasilkan perilaku dan sikap yang berorientasi pada tujuan, memiliki komitmen dalam mengejar tujuan dan mengimplementasikan tindakan dan efikasi diri. Regulasi diri juga akan membantu individu dalam mengontrol diri. Melalui penelitiannya yang dilakukan pada remaja di tahun 2011, Gollwitzer juga mengatakan bahwa melalui regulasi diri, akan tercipta kedisiplinan diri pada remaja yang artinya, remaja akan lebih menghargai waktu dan memiliki kemampuan untuk memilih yang mana yang penting untuk dihadapi saat ini.

Menurut uraian di atas dapat ditarik bahwa regulasi diri merupakan salah satu langkah yang dapat diambil dalam mengurangi prokrastinasi akademik, mengingat pengaruhnya yang bersifat negative dan sebesar 29,3\%. Melalui regulasi diri yang baik, siswa akan mampu mengontrol diri, dan menjadi lebih disiplin dalam memenuhi tujuan-tujuan akademiknya serta meminimalisir permasalahan yang dihadapi saat ini yaitu prokrastinasi akademik.

\section{PENUTUP}

\section{Kesimpulan}

Berdasarkan pengujian secara statistik dapat disimpulkan bahwa terdapat pengaruh signifikan regulasi diri terhadap prokrastinasi akademik. Pengaruh yang dihasilkan bersifat negatif, yang artinya semakin tinggi regulasi diri, maka akan semakin rendah Prokrastinasi Akademik. Pengaruh regulasi diri terhadap prokrastinasi akademik sebesar 29,3\% dan 70,7\% lainnya dipengaruhi oleh faktor lain yang tidak diteliti dalam penelitian ini.

\section{Saran}

Berdasarkan kesimpulan, maka disarankan untuk lebih termotivasi dalam meraih tujuan maupun cita- cita, sehingga memiliki daya regulasi diri dan mampu mengurangi tingkat prokrastinasi akademik. Selain itu, dari hasil penelitian ini diharapkan pihak sekolah dapat mengadakan seminar yang membantu siswa dalam meningkatkan kemampuan meregulasi diri. Guru diharapkan mampu membuat suasana pembelajaran yang menyenangkan untuk mengurangi rasa bosan dan lelah siswa sebagai langkah preventif meningkatnya kecenderungan siswa menunda atau menghindar dalam pengerjaan tugas-tugas akademik.

Bagi peneliti selanjutnya yang tertarik untuk melakukan penelitian dengan tema yang sama, penulis menyarankan untuk memperluas lingkup populasi dan sampel sehingga mampu menggambarkan apakah pengaruh regulasi diri terhadap prokrastinasi akademik juga berlaku pada instansi-instansi pendidikan di wilayah Indonesia lainnya, atau di bangku pendidikan setingkat Sekolah Menengah Pertama. Selain itu, dapat dipertimbangkan untuk menggunakan metode 
penelitian lain, seperti penelitian kualitatif yang mengumpulkan data mendalam melalui observasi dan wawancara pada kasus-kasus regulasi diri dan prokrastinasi akademik pada setting pendidikan yang terbilang unik, misalnya siswa di sekolah inklusi atau pada anak yang mengikuti home-schooling.

\section{DAFTAR PUSTAKA}

Azwar, S. (2010). Metode penelitian. Yogyakarta: Pustaka Pelajar

Azwar, S. (2012). Penyusunan skala psikologi.Yogyakarta: Pustaka Pelajar.

Achtziger, A., Martiny, S. E., Oettingen, G., \& Gollwitzer, P. M. (2012). Metacognitive processes in the self-regulation of goal pursuit. In P. Brinol,\& K. DeMarree (Eds.), Social metacognition (pp. 121-139). New York: Psychology Press.

Bandura, A. (1991). Social cognitive theory of selfregulation. Organizational Behavior and Human Decision Processes, Vol. 50,

Barkley RA. (1997). ADHD and Self Regulation. In: Baumeister RF, Vohs KD (eds). Handbook of Self Regulation, Research, theory, and Applications. New York : Guillford.

Beswick, G., Rothblum, E. D., \& Mann, L. (1988). Psychological antecedents of student procrastination. Australian Psychologist

Blunt, A., \& Pychyl, T. A. (1998). Volitional action and inaction in the lives of undergraduate students: State orientation, procrastination and proneness to boredom. Personality $\mathcal{E}$ Individual Differences.

Boekart.M., Pintrich (2000).Handbook of self regulation. San Diego: Elsevier Academic Press.

Ferrari, J. R. (1989). Reliability of academic and dispositional measures of procrastination. Psychological Reports.

Burka, Jane B. \&Yuen, Lenora M. (1983) Procrastination. Cambridge, MA: Da CapoPress.

Ferrari, J. R. (2000). Time orientations of procrastinators: Focusing on the past, present, or future? Journal of Social Behavior and Personality.

Ferrari, Joseph R, Judith Johnson, and William George McCown. (1995). Procrastination And Task Avoidance. New York: Plenum Press.

Ferrari, J. R. (1996). Dysfunctional procrastination and its relationship with self-esteem, interpersonal dependency, and self-defeating behaviors. Personality $\mathcal{E}$ Individual Differences.

Ferrari, J. R. (2001). Procrastination as self-regulation failure of performance: Effects of cognitive load, self-awareness, and time limits on 'Working Best Under Pressure'. European Journal of Personality.

Ferrari, J. R., Mason, C. P., \& Hammer, C. (2006). Procrastination as a predictor of task perceptions: Examining delayed and non-delayed tasks across varied deadlines. Individual Differences Research.

Gage, N.L \& Berliner, D.C. (1984). Educational Psychology. Boston: Houghton Mifflin Company.

Ghufron, M. N., (2003). Hubungan kontrol diri dan persepsi remaja terhadap penerapan disiplin orang tua dengan prokrastinasi akademik.Universitas Gajah Mada. Tesis.

Gollwitzer,P.M., \& Sheeran, P. (2006). Implementation intentions and goal achievement: A meta-analysis ofeffects and processes. San Diego, CA: Academic Press.

Gollwitzer, P. M., \& Oettingen, G. (2011).Planning promotes goal striving.InK. D. Vohs, \& R. F. Baumeister (Eds.). Handbook of self-regulation: Research, theory, and applications (2nd edn, pp. 162-185). New York, London: The Guilford Press.

Green, L. (1982). Minority students' self-control of procrastination.Journal of Counseling Psychology, Vol. 29.

Harvardedu.com (2016). Executive functions. USA

Hurlock, E. B. (1980). Psikologi perkembangan (suatu pendekatan sepanjang rentan kehidupan). Edisi Kelima. Jakarta: Penerbit Erlangga.

Hurlock, E.B. (1999). Psikologi perkembangan (suatu pendekatan sepanjang rentang kehidupan). Edisi kelima. Jakarta: Penerbit Erlangga

Hurlock, E. B. (2000). Psikologi perkembangan. Jakarta: Erlangga

Kemendikbud. Undang-undang Tentang Pendidikan Nasional No. 20 Tahun 2003.

Kendall, P. \&Hammen, C. (1998). Abnormal psychology (2nd edition).Boston: Houghton-. Mifflin.

Kendemir, M. (2014). Academic Functional Procrastination: Validity and Reliability Study. Procedia. Social and behavioral science.

Klassen, R., Ang, R., Chong, W., Krawchuk, L., Huan, V., Wong, I., \& Yeo, L. (in press). Academic procrastination in two settings: Motivation correlates, behavioral patterns, and negative impact of procrastination in Canada and Singapore. Applied Psychology.

Kountur, R. (2007). Metodologi penelitian untuk 
penulisan skripsi dan tesis edisi revisi. Jakarta: Percetakan Buana Printing.

McCloskey, J. (2011). Academic procrastination. Thesis. University of Texas.

Moilanen, Kristin. (2007). The adolescent selfregulation inventory: The development and validation of questionnaire of shor term and long term self-regulation. Journal of Youth and Adolescence.

Oettingen, G. \& Gollwitzer, P.M. (2000).Effective Self Regulation of Goal Attainment.European Journal of Social Psychology.

Oettingen, G. \& Gollwitzer, P.M. (2005). Self regulation of time management. Interational Journal of Education Research.

Papalia, D. E., Olds, S. W.,\& Feldman, R. D. (2008). Human development (psikologi perkembangan) edisi kesembilan. Jakarta: Kencana.

Poerwadarminta. W. J. S. (2006). Kamus Umum Bahasa Indonesia. Jakarta: PNBalai Pustaka.

Pychyl, T. A., Lee, J. M., Thibodeau, R., \& Blunt, A. (2000). Five days of emotion: An experience sampling study of undergraduate student procrastination. Journal of Social Behavior and Personality, Vol. 15.

Rachmahana, R. S. (2002). Perilaku prokrastinasi akademik pada mahasiswa. Psikodimensia Kajian Ilmiah Psikologi. Vol. 2.No. 3.

Rangkuti, A. A., Listyasari, W. D., Hapsari, I. I.,\& Wahyuni, L. D. (2015). Penulisan ilmiah dalam psikologi. Jakarta: Lembaga Pengembangan Pendidikan Universitas Negeri Jakarta.

Rangkuti, A. A. (2012). Konsep dan teknik analisis data penelitian kuantitatif bidang psikologi dan pendidikan. Jakarta: FIP Press.

Rangkuti, A. A. (2013). Statistika inferensial untuk penelitian psikologi dan pendidikan. Jakarta: FIP UNJ.

Sangadji, E. M.,\& Sopiah. (2010). Metodologi penelitian: pendekatan praktis dalam penelitian. Yogyakarta: Penerbit ANDI.

Schunk, D.H., \& Ermer, P.A. (2000). Self Regulation and academic learning: Self Efficacy Enhancing.

Sciarra, T. (2004). School counseling: Foundations and themporary issues. Thomson/Brooks/Cole: University of Virginia.

Senecal et. al,. (1995). Self-regulation and academic procrastination. The Journal of Social Psychology, Vol.5.

Sperling, R. (2012). Patterns of procrastination, motivation, and strategy use across class contexts and students' abilities. Journal of Psychology and Behavioral Sciences, Vol.5.

Sugiyono (2011). Metode penelitian kuantitatif, kualitatif, dan RED. Bandung: Alfabeta.

Sumintono, B., \& Widhiarso, W. (2013). Aplikasi model rasch untuk penelitian ilmu-ilmu sosial. Cimahi: Trim Komunikata Publishing House.

Suratri, R. D. (2009). Statistik deskriptif: Statistika dasar psikologi dan pendidikan. Jakarta: FIP UNJ.

Steel, P. (2002). The measurement and nature of procrastination.Unpublished $\mathrm{PhD}$, University of Minnesota, Minneapolis.

Steel, P. (2007). The nature of procrastination: A metaanalytic and theoretical review of quintessential self-regulatory failure. Psychological Bulletin, 133, 65-94.

Solomon, L. J., \& Rothblum, E. D. (1984). Academic procrastination: Frequency and cognitivebehavioral correlates. Journal of Counseling Psychology, 31(4), 503-509.

Schouwenburg, H. C. (1995). Academic procrastination: Theoretical notions, measurement, and research. In J. R. Ferrari \& J. L. Johnson (Eds.). Procrastination and task avoidance: Theory, research, and treatment.

Tice, D. M., \& Baumeister, R. F. (1997). Longitudinal study of procrastination, performance, stress, and health: The costs and benefits of dawdling. Psychological Science, Vol. 8.

Tuckman, B. W. (1991). The development and concurrent validity of the procrastination scale. Educational \& Psychological Measurement, 51, 473-480.

Van Hooft, E. A. J., Born, M. P., Taris, T. W., Van der Flier, H., \& Blonk, R. W. B. (2005).Bridging the gap between intentions and behavior: Implementation intentions, action control, and procrastination. Journal of Vocational Behavior, 66(2).

Watson, L.A. Clark, A. Tellegen. Development and validation of brief measures of positive and negative affect: the PANAS scales. Journal of Personality and Social Psychology, Vol.54.

Walgito, B. (1990). Pengantar psikologi umum. Yogyakarta: Psikologi UGM.

Zimmerman, B. J., Greenberg, D., \& Weinstein, C. E. (1994).Self-regulating academic study time: A strategy approach. In D. H. Schunk, \& B. J. Zimmerman (Eds.). Self-regulation oflearning and performance: Issues and educational applications (pp.181-199). Hillsdale, NJ: Lawrence Erlbaum 
Pengaruh Regulasi Diri ...

Associates, Inc.

Zimmerman, B. J. (2000). Attaining self regulation. In: P.R Pintrich \& M. Zaidner (Ed.). Handbook of self regulation. San Diego: Academic Press. 